\title{
The efficacy of thoracic epidural and paravertebral blocks for post-thoracotomy pain management
}

\author{
Gonul Sagiroglu ${ }^{1}$, Ayse Baysal ${ }^{2}$, Elif Copuroglu ${ }^{1}$, Yekta Altemur Karamustafaoglu ${ }^{3}$, Tamer Sagiroglu ${ }^{4}$, \\ Volkan Yuksel ${ }^{5}$, Serhat Huseyin ${ }^{5}$ \\ ${ }^{1}$ Department of Anesthesiology, Trakya University, Faculty of Medicine, Edirne, Turkey \\ 2Department of Anesthesiology, Kartal Kosuyolu Yuksek Ihtisas Training and Research Hospital, Istanbul, \\ Turkey \\ ${ }^{3}$ Department of Thoracic Surgery, Trakya University, Faculty of Medicine, Edirne, Turkey \\ ${ }^{4}$ Department of General Surgery, Trakya University, Faculty of Medicine, Edirne, Turkey \\ ${ }^{5}$ Department of Cardiovascular Surgery, Trakya University, Faculty of Medicine, Edirne, Turkey \\ Kardiochirurgia i Torakochirurgia Polska 2013; 10 (2): 139-148
}

\begin{abstract}
Introduction: The definition of pain focuses mainly on tissue damage and provides information regarding pathophysiological changes in the human being [1]. Patients experience pain as a response to this tissue damage after surgery and the pain intensity after thoracotomies is known to be severe [2].

Aim of the study: Our goal was to investigate the efficacy and adverse effects of thoracic epidural and paravertebral blocks for post-thoracotomy pain management.

Material and methods: In a prospective, randomized double blinded study, patients were divided into thoracic epidural (EPI group, $n=30$ ) and paravertebral (PVB group, $n=30$ ) groups. A bolus dose of $10 \mathrm{ml}$ of $0.25 \%$ bupivacaine was followed by a continuous infusion of $0.1 \mathrm{ml} \mathrm{kg}^{-1} \mathrm{~h}^{-1}$ for a total of 24 hours. A visual analog scale (VAS) was used to evaluate pain at rest (VAS-R) and after coughing (VAS-C) at baseline (after extubation), 2, 4, 12 and 24 hours after surgery. The duration of catheter insertion, morphine consumption, complications and side effects were collected.

Results: In comparison of EPI and PVB groups, VAS-R and VASC scores were similar at baseline and at 2, 4, 12 and 24 hours after surgery $(p>0.05)$. The incidence of hypotension was higher and the duration of catheter insertion was longer in the EPI group in comparison to the PVB group ( $p=0.038, p<0.0001$, respectively).

Conclusions: For post-thoracotomy pain, both thoracic epidural analgesia and paravertebral block techniques provide sufficient pain relief. As paravertebral block is an easier and quicker technique with lower incidence of hypotension, it should be considered as a good alternative to thoracic epidural technique to establish postoperative analgesia.

Key words: thoracotomy, postoperative analgesia, thoracic paravertebral block, thoracic epidural analgesia, complication.
\end{abstract}

\section{Streszczenie}

Wstęp: Definicja bólu koncentruje się głównie na uszkodzeniu tkanek i informacjach dotyczących zmian patofizjologicznych. Chorzy doświadczają bólu w odpowiedzi na uszkodzenie tkanki po zabiegu operacyjnym, a jego intensywność po operacji torakochirurgicznej jest duża.

Cel pracy: Celem pracy była ocena skuteczności i skutków ubocznych zastosowania w piersiowym odcinku kręgosłupa nadtwardówkowej i przykręgowej blokady w leczeniu bólu po torakotomii.

Materiał i metody: W prospektywnym, z podwójnie ślepą próbą badaniu z randomizacją, pacjenci zostali podzieleni na dwie grupy w zależności od sposobu znieczulenia piersiowego odcinka kręgosłupa: nadtwardówkowego (grupa EPI, $n=30$ ) i przykręgowego [grupa PVB, $n=30$ ]. Po podaniu bolusa $10 \mathrm{ml} 0,25 \%$ bupiwakainy kontynuowano ciągły wlew leku przez okres 24 godzin w dawce $0,1 \mathrm{ml} \mathrm{mL} \mathrm{kg} \mathrm{kh}^{-1}$. Analogowa skala wzrokowa została użyta do oceny intensywności bólu w spoczynku (VAS-R) i po kaszlu (VAS-C) wyjściowo (po ekstubacji) oraz w 2., 4., 12. i 24. godzinie po operacji. Oceniano czas stosowania cewnika, dawek morfiny oraz powikłań i skutków ubocznych znieczulenia.

Wyniki: Natężenie bólu VAS-R i VAS-C w obydwu grupach było podobne zarówno wyjściowo, jak i w 2., 4., 12. i 24. godzinie po operacji $(p>0,05)$. W grupie EPI w porównaniu z grupą PVB stwierdzono większą częstość występowania hipotensji i dłuższy czas stosowania cewnika ( $p=0,038, p<0,0001)$.

Wnioski: Zarówno technika z użyciem nadtwardówkowego, jak i przykręgowego znieczulenia są skuteczne w leczeniu bólu po torakotomii. Blokada przykręgowa jest techniką prostszą z rzadszym występowaniem hipotensji, dlatego powinna być rozważana jako dobra alternatywa dla techniki nadtwardówkowej.

Słowa kluczowe: torakotomia, pooperacyjne znieczulenie, piersiowa blokada przykręgowa, piersiowe nadtwardówkowe znieczulenie, powikłanie.

Address for correspondence: Assoc. Prof. Dr Yekta Karamustafaoglu, Trakya University Faculty of Medicine, Department of Thoracic Surgery, 22030 Edirne, Turkey, tel. +902842355936, e-mail: altemurk@hotmail.com. 


\section{Introduction}

The definition of pain focuses mainly on tissue damage and provides information regarding pathophysiological changes in the human being [1]. Patients experience pain as a response to this tissue damage after surgery and the pain intensity after thoracotomies is known to be severe [2]. In addition to substantial patient discomfort, postoperative pain results in physiological changes, affecting the function of the respiratory, cardiovascular, gastrointestinal, urinary, musculoskeletal, and neuroendocrine systems [3].

Although thoracic epidural analgesia is a well-known technique for pain relief after thoracotomies, it is associated with many adverse effects such as hypotension, respiratory depression, urinary retention, incomplete or failed block, and, in rare cases, paraplegia [4].

Paravertebral block is an alternative technique that has been investigated for its beneficial effects on pain relief. The use of intermittent bolus doses of local anesthetics or continuous infusion of local anesthetics through a paravertebral catheter was considered for post-thoracotomy pain relief with or without the use of additional systemic opioids [5].

Our primary goal was to design a prospective, randomized, double-blinded study masked to observers to compare the use of paravertebral block and thoracic epidural analgesia after thoracotomies for postoperative analgesia. There are still few well-designed, randomized trials on the clinical use of paravertebral block in thoracotomy patients [6-9]. It is not clear whether it has a significant beneficial effect on pain or pain related postoperative complications.

Our secondary goal was to investigate several perioperative parameters including respiratory related complications which have an influence on outcome in patients undergoing thoracotomy. The differences of all intraoperative (operation type, duration of surgery, Charlson co-morbidity index, use of blood products) and postoperative (morphine consumption, adverse events, complications) parameters were compared between thoracic epidural versus paravertebral block techniques.

\section{Material and methods}

After institutional review board approval and written informed consent, sixty-eight adult consecutive patients with ages between 19 and 86 were enrolled in a prospective, randomized, double-blinded study for post-thoracotomy pain relief. The American Society of Anesthesiologists (ASA) classifications of the patients were I, II or III. All patients were undergoing posterolateral thoracotomy for thoracic tumor removal.

Randomization into two groups was performed using sealed envelopes. The sequentially numbered assignment of the participant was concealed in an envelope. This envelope was opened before anesthesia induction by health care personnel. The observers who collect the visual analogue scale (VAS) scores and other data were blinded to the pain relief protocol. Information of the method of pain relief and the medication that was used for pain relief was not provided to the observers. Caregivers (nurses and doc- tors) were not blinded, but they did not participate in data collection or data interpretation. The study protocol is considered double-blinded, masked to observers.

All surgical procedures were performed by the same surgical team through a posterolateral thoracotomy incision through the fifth or sixth rib $\left(T_{5}\right.$ or $\left.T_{6}\right)$, a PVB catheter was inserted by the same surgeon at the end of surgery and all thoracic epidural catheter placements were performed by the same anesthesiologist. As many of our patients present with local advanced tumors (chest wall, pericardium, central vascular and main branch) or pleural adhesions due to tuberculosis or inflammatory diseases a posterolateral thoracotomy for thoracic tumor removal is needed.

From a total of 68 patients who fulfilled the inclusion criteria, eight of them did not complete the study. Six patients were unable to complete the study secondary to problems related to thoracic epidural catheter insertion or discontinuance of infusion of local anesthetic after dislocation of the catheter from its place, two patients were transferred to the intensive care unit on mechanical ventilation and one patient underwent rethoracotomy within the first twenty-four hours postoperatively. A consort diagram is presented in Fig. 1.

Exclusion criteria from the study included contraindications for epidural catheter placement (puncture in the skin, infection, bacteremia, hypovolemia, platelet count $<100000 \mathrm{~mm}^{-3}$, prolonged coagulation tests, vertebral column deformity), preoperative pulmonary dysfunction [forced vital capacity (FVC) $<60 \%$ or the first second forced expiratory volume $\left(\mathrm{FEV}_{1}\right)<60 \%$ ], chronic pain because of the constant use of analgesic drugs, liver or kidney failure, alcohol abuse or drug abuse, and a history of allergy to local anesthetics.

Demographic data, age, height, weight, body mass index (BMI), smoking, having neoadjuvant therapy, pulmonary function parameters, histological type of cancer, and surgical procedures were recorded. Preoperative pulmonary function tests were determined. The $\mathrm{FEV}_{1}$ (\% predicted) and FVC (\% predicted) values were calculated. Preoperatively and at 2, 4, 12 and 24 hours during the postoperative period arterial blood gas $\mathrm{PaO}_{2}$ (arterial partial pressure of oxygen), $\mathrm{PCO}_{2}$ (arterial partial pressure of carbon dioxide) and $\mathrm{SaO}_{2}$ (arterial oxygen saturation) values in addition to hemodynamic data including systolic, diastolic and mean arterial pressures (peripheral oxygen saturation) were also recorded. Comorbidities were defined and graded according to the Charlson comorbidity index. Nineteen conditions were defined as significantly influencing survival in the study population and were given a weighted score based on the relative mortality risk. The sum of the weighted scores of all the comorbid conditions in cancer patients was then scaled to establish the Charlson comorbidity index. The weights range from 1 to 6 ( 0 if the comorbidity is absent) and four Charlson comorbidity index classes were defined as 0, 1-2, 3-4 and $\geq 5$ [6].

Patients were randomized to receive thoracic epidural (EPI group, $n=30$ ) or intercostal block (PVB group, $n=30$ ) 


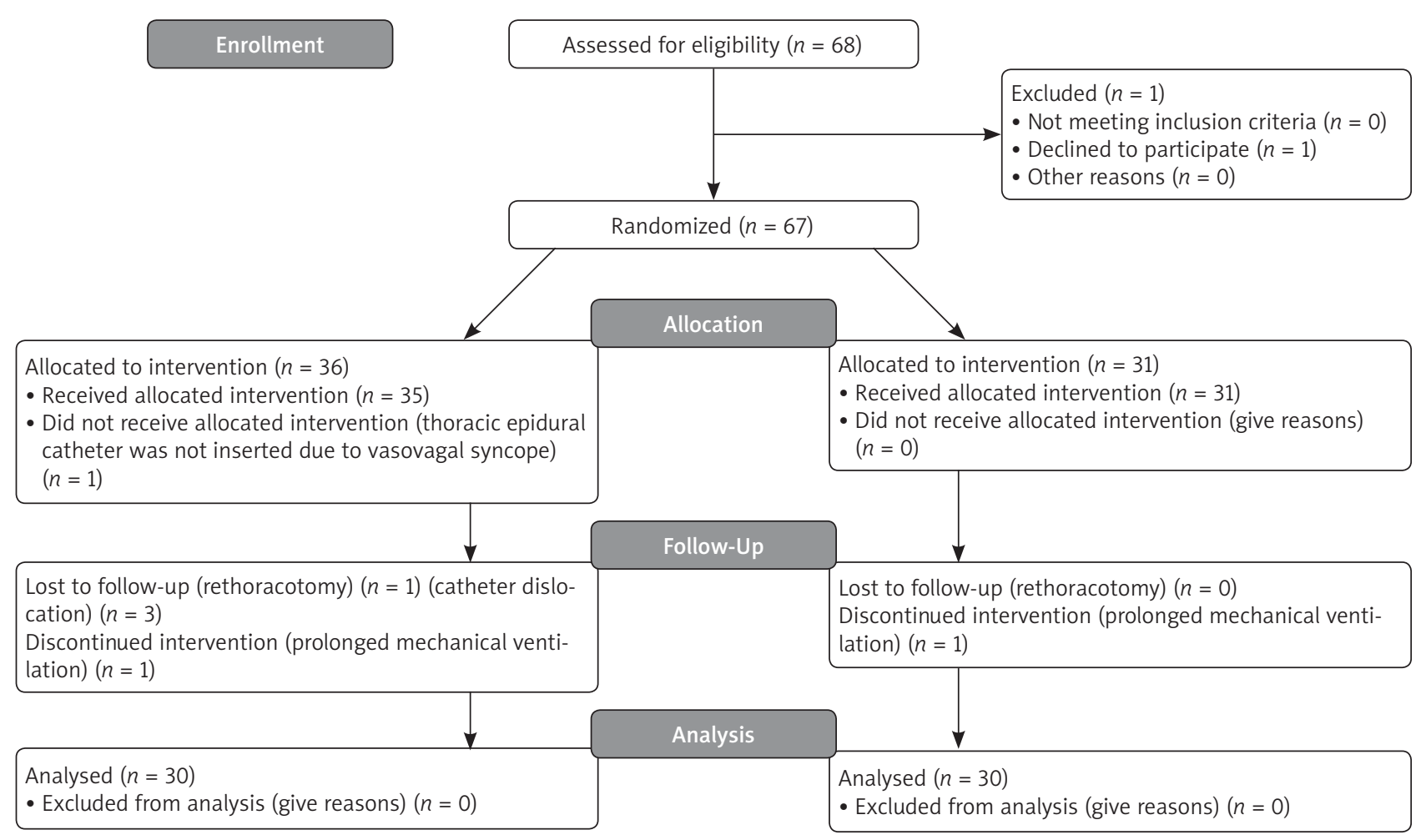

Fig. 1. CONSORT 2010 Flow Diagram

for 24 hours from the inserted catheter. In both groups, a bolus dose of $10 \mathrm{ml}$ of $0.25 \%$ bupivacaine (Bustesin $0.5 \%$, Vem Pharmaceutical, Turkey), was administered from the thoracic paravertebral catheter before surgical closure. Afterwards, $0.25 \%$ bupivacaine was infused at a rate of $0.1 \mathrm{ml} / \mathrm{kg} / \mathrm{h}$ from the inserted catheter (either thoracic epidural or paravertebral) for a total of 24 hours.

On arrival at the operating room, before general anesthesia, in the thoracic epidural group of patients, after sterile preparation of the thoracic region, a thoracic epidural catheter (Epidural Minipack, Portex, Turkey) was placed in the thoracic epidural spaces at the $T_{5}-T_{7}$ level using a 16-gauge Tuohy needle (B-Braun Medical, Abbott, Turkey) with loss of resistance technique in the sitting position. The catheter was advanced 4 to $5 \mathrm{~cm}$ inside the epidural space and a test dose of $3 \mathrm{ml}$ lidocaine $2 \%$ (Jetmonal $2 \%$, Adeka Pharmaceutical, Turkey) with epinephrine $5 \mu \mathrm{g} / \mathrm{ml}$ was given to exclude misplacement of the catheter. Misplacement of the thoracic epidural catheter is tested after insertion of the catheter by aspiration of blood or colored fluids to check for hemorrhage, insertion of the catheter into other cavities such as pleura or intravertebral foramen. Another sign of misplacement is lack of injection of fluids from the catheter. The patient is followed for pain relief on the ipsilateral thoracotomy site and if there is no pain relief, dislodgement of the catheter is suspected.

The technical aspect of paravertebral catheter placement is as follows. Our preference is that before thoracotomy closure, the parietal pleura is elevated to the vertebral column and blunt dissection of the endothoracic fascia, two dermatomes above and two below the incision, is performed. An externally introduced 18-gauge Tuohy needle (B-Braun Medical, Abbott, Turkey) was inserted into the paravertebral space and the catheter was advanced into position alongside the vertebral bodies and fixed to the skin with suture. The catheter was advanced $4-5 \mathrm{~cm}$ into the paravertebral space and a test dose of $3 \mathrm{ml}$ lidocaine 2\% (Jetmonal 2\%, Adeka Pharmaceutical, Turkey) with epinephrine $5 \mu \mathrm{g} / \mathrm{ml}$ was given to exclude misplacement of the catheter. Both catheters were secured to the skin with sutures and fixing materials.

VAS was used to evaluate pain at rest (VAS-R) and after coughing (VAS-C) at baseline (after extubation), 2, 4, 12 and 24 hours after surgery. The duration of catheter insertion, morphine consumption, side effects and complications were collected.

In all patients anesthesia induction was conducted with the use of intravenous doses of sodium thiopental 5-6 mg/ kg (Pental, IE Ulugay Pharmaceutical Industry, Turkey), fentanyl (fentanyl Janssen, Janssen Pharmaceutica, Belgium) $2 \mu \mathrm{g} / \mathrm{kg}$, rocuronium bromide $0.6 \mathrm{mg} \mathrm{kg}^{-1}$ (Esmeron, Organon Pharmaceuticals, U.S.A.) and $100 \% \mathrm{O}_{2}$ A double lumen endobronchial intubation (Broncho-cath; Mallinckrodt, Dublin, Ireland) was performed. The correct placement of the tube was confirmed by fiberoptic bronchoscopy. After anesthesia induction, radial artery cannulation via a 20-gauge needle was performed to collect hemodynamic data including blood pressure, heart rate and arterial blood gas values. Anesthesia was maintained with 70\% $\mathrm{O}_{2}, 30 \%$ air, 1-2\% MAC (minimum alveolar concentration) 
of isoflurane, and every hour an intravenous bolus dose of fentanyl $1 \mu \mathrm{g} / \mathrm{kg}$ and vecuronium $0.03 \mathrm{mg} / \mathrm{kg}$. At the end of the operation, neuromuscular block was reversed by the administration of intravenous neostigmine at a dose of $0.7 \mathrm{mg} / \mathrm{kg}$ and atropine at a dose of $0.02 \mathrm{mg} / \mathrm{kg}$. The duration of the operation, the total amount of packed red blood cells (RBC) and fresh frozen plasma (FFP) solutions during surgery, and length of hospital stay were also recorded.

In all patients, the trachea was extubated at the end of surgery. After insertion of catheters, hypotension (decrease of MAP below $20 \%$ of baseline MAP) was treated with infusion of a bolus of isotonic fluid solution and intravenous ephedrine (Ephedrine, Osel Pharmaceutical, Turkey) at a bolus dose of $10 \mathrm{mg}$. Bradycardia ( $\mathrm{HR}<50$ beats/min) was treated with intravenous atropine (Atropin sulfate, Biofarma Pharmaceutical, Turkey) at a bolus dose of $0.5 \mathrm{mg}$. The incidence of vomiting was treated with intravenous dexamethasone $8 \mathrm{mg}$ (Dexoject, Mefar Pharmaceutical, Turkey) and nausea was treated with intravenous ondansetron $4 \mathrm{mg}$ (Zofran $8 \mathrm{mg}$, Glaxo Smith Kline Pharmaceutical, Turkey). Respiratory depression (respiratory rate below 8 per min) was treated with $100 \%$ oxygen supplementation via a face mask.

In both groups of patients, intravenous 1000 mg paracetamol (Perfalgan, Bristol-Myers Squibb Pharmaceutical, France) and intravenous $50 \mathrm{mg}$ diclofenac (Dikloron, Deva Pharmaceutical, Turkey) were administered every 8 hours on the first postoperative day.

\section{Endpoints}

The primary endpoint was pain at rest and on coughing. Pain intensity was measured at rest (VAS-R) and after coughing (VAS-C) using a VAS in which $0 \mathrm{~cm}$ is no pain and $10 \mathrm{~cm}$ is the worst pain possible. The pain was assessed by a blinded observer at baseline and at 2, 4, 12 and 24 hours after surgery. Also, Wilson sedation score $(1=$ fully awake and oriented; 2 = drowsy; 3 = eyes closed, but rousable with command; 4 = eyes closed, but rousable with mild physical stimulation; 5 = eyes closed, but not rousable with mild physical stimulation) was performed at the same time points postoperatively. Nausea/vomiting was evaluated as $0=$ absent, 1 = mild nausea, and 2 = severe nausea and/or vomiting. A VAS-R score of $4 \mathrm{~cm}$ or less was considered to be an acceptable level of pain. If the VAS-R score was more than $4 \mathrm{~cm}$, patients received an intravenous $2 \mathrm{mg}$ dose of morphine (Morphine HCL, Galen Pharmaceutical, Turkey) every 10 minutes for a maximum dose of $10 \mathrm{mg}$ every hour. All changes related to pain relief were made by the pain service physicians who were not blinded to the type of analgesia that each patient receives.

Secondary end points were total 24-hour morphine consumption, use of 24-hour local anesthetic, morphinerelated side effects (nausea and vomiting, urinary retention, pruritus, and sedation), and adverse effects. Also, 30-day postoperative side effects related to postoperative analgesia technique and complications (respiratory failure, atelectasis, pneumonia, bronchoscopy and suction, tracheostomy, reintubation, postoperative bleeding, bronchop- leural fistula, rethoracotomy, in-hospital and 30-day mortality) were recorded.

\section{Statistical analysis}

All statistical analysis was performed using SPSS Statistical Package 15.0 (SPSS Inc. California, USA). For sample size analysis the program PASS 11 (NCSS Inc. Utah, USA) was used. The sample size was determined as follows: for a clinically significant change in VAS-R value of $2 \mathrm{~cm}$ and a VAS$R$ standard deviation of $2 \mathrm{~cm}$ between groups with a confidence interval of $95 \%$ and $80 \%$ power, 21 patients need to be included for each group [10]. Data are presented as mean and standard deviation (SD) or as frequencies and percentages. Differences were assessed using chi square or Fisher exact test for categorical variables. Mann Whitney U-test was used for continuous or non-parametric data. After testing for normal distribution, data were compared using a two-way analysis of variance (ANOVA) for repeated measurements. $P$ values $<0.05$ were considered statistically significant.

\section{Results}

There were no statistically significant differences regarding age, sex, or weight and perioperative clinical characteristics between groups 1 and $2(p>0.05)$ (Table I).

The comparison of types of surgical procedures between groups included: lobectomy [9 (30\%) vs. 12 (40\%); $p=0.417$ ], bilobectomy [4 (13.3\%) vs. $3(10 \%) ; p=0.688$ ], pneumonectomy [7 (23.3\%) vs. 10 (33.3\%); $p=0.39$ ], wedge resection [6 (20\%) vs. 4 (13.3\%); $p=0.488$ ], cystostomy and capitonnage [4 (13.3\%) vs. 1 (3.3\%); $p=0.161$ ] and these were not found to be statistically different between groups $(p>0.05)$ (Table I).

In the EPI group, FEV 1 and FVC values (80.33 \pm 1.49 , $79.8 \pm 1.4$, respectively) showed no significant difference in comparison to the values of the PVB group $(79.6 \pm 1.33$, $79.9 \pm 1.74$, respectively) $(p>0.05)$.

The comparison of $\mathrm{PaO}_{2}, \mathrm{PCO}_{2}$, and $\mathrm{SaO}_{2}$ values preoperatively and postoperatively at 2, 4, 12 and 24 hours showed no difference between groups 1 and $2(p>0.05)$ (Table II).

The comparison of postoperative hemodynamic parameters between groups including SAP, DAP, MAP, HR and $\mathrm{SpO}_{2}$ at baseline (after extubation) and 2, 4, 12 and 24 hours postoperatively showed no significant difference between groups $(p>0.05)$ (Table III).

In comparison of the EPI group and the PVB group, VAS$R$ and VAS-C scores were similar at baseline and at 2, 4, 12 and 24 hours after surgery $(p>0.05)$ (Table IV and V). In comparison to the basal values, the VAS-R values at 2, 4, 12 and 24 hours were significantly lower in the EPI group $(p=0.0014 ; p<0.0001 ; p<0.0001 ; p<0.0001$, respectively) (Table IV). In comparison to the basal values, the VAS-R values at 2, 4, 12 and 24 hours were significantly lower in the PVB group ( $p<0.0001 ; p<0.0001 ; p<0.0001 ; p<0.0001$, respectively) (Table IV).

In both groups, the VAS-C values at 2, 4, 12 and 24 hours were significantly lower than basal values $(p<0.0001$; $p<0.0001 ; p<0.0001 ; p<0.0001$, respectively) (Table V). 
Tab. I. Comparison of demographic data and perioperative clinical characteristics of patients in thoracic epidural and paravertebral groups

\begin{tabular}{|c|c|c|c|c|c|}
\hline \multirow{2}{*}{ Patients } & \multicolumn{2}{|c|}{ EPI group $(n=30)$} & \multicolumn{2}{|c|}{ PVB group $(n=30)$} & \multirow{2}{*}{$P$} \\
\hline & Median & Quartile range & Median & Quartile range & \\
\hline Age (years) & 58 & $27-78$ & 58.5 & $21-81$ & 0.951 \\
\hline Sex $\left(n^{\star}\right.$, female/male) & $3 / 27$ & & $6 / 24$ & & 0.278 \\
\hline Weight (kg) & 70 & $55-104$ & 71 & $50-92$ & 0.502 \\
\hline Height $(\mathrm{cm})$ & 174 & $160-185$ & 169 & 158-189 & 0.448 \\
\hline Body mass index $\left(\mathrm{kg} / \mathrm{m}^{2}\right)$ & 24.5 & $16-36$ & 24 & $18-31$ & 0.92 \\
\hline Smoking status; $n$ (\%) & $27(90)$ & & $24(80)$ & 0.278 & 0.278 \\
\hline Neoadjuvant therapy & $7(23.3)$ & & $4(13.3)$ & 0.317 & 0.488 \\
\hline ASA classification (I/II/III) & $3 / 16 / 11$ & & $5 / 18 / 7$ & & 0.471 \\
\hline $\begin{array}{l}\text { Charlson comorbidity index } \\
0 \\
1 \\
\geq 2\end{array}$ & $\begin{array}{c}2(6.7) \\
20(66.7) \\
7(23.3)\end{array}$ & & $\begin{array}{c}5(16.7) \\
23(76.7) \\
2(6.7)\end{array}$ & & $\begin{array}{l}0.228 \\
0.39 \\
0.071\end{array}$ \\
\hline $\begin{array}{l}\text { Surgical procedure; } n \text { (\%) } \\
\text { Lobectomy } \\
\text { Bilobectomy } \\
\text { Pneumonectomy } \\
\text { Wedge resection } \\
\text { Cystotomy and capitonnage }\end{array}$ & $\begin{array}{c}9(30) \\
4(13.3) \\
7(23.3) \\
6(20) \\
4(13.3)\end{array}$ & & $\begin{array}{c}12(40) \\
3(10) \\
10(33.3) \\
4(13.3) \\
1(3.3)\end{array}$ & & $\begin{array}{c}0.417 \\
0.688 \\
0.39 \\
0.488 \\
0.161 \\
\end{array}$ \\
\hline $\begin{array}{l}\text { Surgical side } \\
\text { Right } \\
\text { Left } \\
\text { Unable to place the catheter } \\
\text { Ephedrine requirement }(\mathrm{mg}) \\
\text { Cumulative local anesthetic consumption (ml) } \\
\text { Additional morphine sulfate consumption (mg) } \\
\text { Duration of the procedure (min) } \\
\text { Duration of surgery (min) } \\
\text { Hospital stay (days) }\end{array}$ & $\begin{array}{l}21(70) \\
9(30) \\
3(10) \\
5.5 \pm 9.4 \\
170 \pm 17 \\
7.33 \pm 8.28 \\
9.47 \pm 1.87 \\
257 \pm 75 \\
8 \\
\end{array}$ & $\begin{array}{c}140-210 \\
0-25 \\
0-20 \\
130-305 \\
(5-25) \\
\end{array}$ & $\begin{array}{c}16(53) \\
14(47) \\
0 \\
1.67 \pm 5.14 \\
180 \pm 22 \\
11.33 \pm 7.62 \\
8.06 \pm 1.68 \\
244 \pm 78 \\
10\end{array}$ & $\begin{array}{c}144-220 \\
4-32 \\
4-32 \\
120-330 \\
(6-30) \\
\end{array}$ & $\begin{array}{l}0.184 \\
0.076 \\
0.055 \\
0.052 \\
0.056 \\
0.003^{*} \\
0.512 \\
0.203 \\
\end{array}$ \\
\hline
\end{tabular}

${ }^{*} P<0.05$ : statistically significant; Data listed as mean \pm SD or number of patients per category; EPI group - thoracic epidural group, PVB group - paravertebral group; ASA - American Society of Anesthesiologists; COPD - chronic obstructive pulmonary disease

Tab. II. Comparison of arterial blood gas values preoperatively and postoperatively at 0, 2, 12 and 24 hours in both groups

\begin{tabular}{|c|c|c|c|c|}
\hline & Preoperative & $2^{\text {nd }}$ hour & $12^{\text {th }}$ hour & $24^{\text {th }}$ hour \\
\hline $\begin{array}{l}\mathrm{PaO}_{2}(\mathrm{~mm} \mathrm{Hg}) \\
\mathrm{EPI} \\
\mathrm{PVB}\end{array}$ & $\begin{array}{l}159.1 \pm 66.04 \\
145.2 \pm 69.06\end{array}$ & $\begin{array}{l}158.33 \pm 69.06 \\
141.63 \pm 42.73\end{array}$ & $\begin{array}{l}135.8 \pm 41.58 \\
130.6 \pm 36.36\end{array}$ & $\begin{array}{r}145.9 \pm 38.51 \\
148.13 \pm 71.95\end{array}$ \\
\hline $\begin{array}{l}\mathrm{PaCO}_{2}(\mathrm{~mm} \mathrm{Hg}) \\
\mathrm{EPI} \\
\mathrm{PVB}\end{array}$ & $\begin{array}{c}42.4 \pm 6.4 \\
42.63 \pm 5.62\end{array}$ & $\begin{array}{c}45 \pm 7.26 \\
43.4 \pm 6.26\end{array}$ & $\begin{array}{c}41.83 \pm 5.6 \\
42.47 \pm 5.22\end{array}$ & $\begin{array}{c}41.87 \pm 6.98 \\
42.86 \pm 6.1\end{array}$ \\
\hline $\begin{array}{l}\mathrm{SaO}_{2}(\%) \\
\mathrm{EPI} \\
\mathrm{PVB}\end{array}$ & $\begin{array}{l}95.63 \pm 3.93 \\
96.93 \pm 3.12\end{array}$ & $\begin{array}{l}94.43 \pm 4.4 \\
93.6 \pm 4.58\end{array}$ & $\begin{array}{c}95.78 \pm 4.28 \\
93.27 \pm 16.42\end{array}$ & $\begin{array}{l}95.83 \pm 4.32 \\
95.13 \pm 4.47\end{array}$ \\
\hline
\end{tabular}

Comparison between groups, $P>0.05$; Data listed as mean \pm SD or number of patients per category; EPI group - thoracic epidural group, PVB group - paravertebral group; $\mathrm{PaO}_{2}$ - arterial partial pressure of oxygen; $\mathrm{PaCO}_{2}$ - arterial partial pressure of carbon dioxide; $\mathrm{SaO}_{2}$ - arterial oxygen saturation

Total amount of local anesthetic consumption in the EPI group $(170 \pm 17 \mathrm{ml})$ was lower than the PVB group $(180 \pm 22 \mathrm{ml})$; however, there was no significant difference between the two groups ( $p=0.052$ ). The use of additional morphine sulfate during the postoperative 24 hours in the EPI group $(7.33 \pm 8.28 \mathrm{mg}$ ) was lower than the PVB group (11.33 $\pm 7.62 \mathrm{mg})$ but this difference was not statistically significant $(p=0.056)$. In summary, the postoperative 24-hour use of additional analgesic morphine, total amount of analgesic consumption and side effects were similar (Table I).
In both groups of patients, respiratory depression caused by postoperative analgesia was not observed. Wilson's sedation score was used to investigate sedation related to postoperative analgesia. Wilson's sedation scores were similar at $0,2,4,12$ and 24 hours postoperatively $(p=0.775 ; p=0.089$; $p=0.142 ; p=0.098 ; p=0.094$, respectively).

The evaluation of adverse events related to the two different pain relief methods revealed that, during the first 24 hours postoperatively, in the EPI group, 8 of 30 patients (26.7\%) experienced hypotension compared with 2 of 30 pa- 
The efficacy of thoracic epidural and paravertebral blocks for post-thoracotomy pain management

Tab. III. Comparison of postoperative hemodynamic parameters between groups*

\begin{tabular}{|c|c|c|c|c|c|c|c|}
\hline Variable & Basal & 1 & 2 & 4 & 8 & 12 & 24 \\
\hline $\begin{array}{l}\operatorname{SAP}^{*}(\mathrm{~mm} \mathrm{Hg}) \\
\text { EPI group }^{*} \\
\text { PVB group* }\end{array}$ & $\begin{array}{l}112(75-152) \\
121(75-170)\end{array}$ & $\begin{array}{l}111(88-147) \\
119(88-175)\end{array}$ & $\begin{array}{l}115(93-156) \\
122(93-181)\end{array}$ & $\begin{array}{l}115(88-151) \\
123(88-188)\end{array}$ & $\begin{array}{l}119(93-152) \\
128(95-180)\end{array}$ & $\begin{array}{l}120(92-153) \\
126(92-180)\end{array}$ & $\begin{array}{l}118(94-159) \\
125(94-159)\end{array}$ \\
\hline $\begin{array}{l}\mathrm{DAP}^{\star}(\mathrm{mm} \mathrm{Hg}) \\
\text { EPI group } \\
\text { PVB group }\end{array}$ & $\begin{array}{c}66(45-101) \\
70(45-99)\end{array}$ & $\begin{array}{l}67(46-98) \\
70(46-89)\end{array}$ & $\begin{array}{l}68 \text { (46-101) } \\
71(46-101)\end{array}$ & $\begin{array}{c}71(53-92) \\
74(53-104)\end{array}$ & $\begin{array}{l}70(42-96) \\
75(42-96)\end{array}$ & $\begin{array}{l}71(41-93) \\
74(41-95)\end{array}$ & $\begin{array}{l}70(51-91) \\
73(51-91)\end{array}$ \\
\hline $\begin{array}{l}\mathrm{MAP}^{\star}(\mathrm{mm} \mathrm{Hg}) \\
\text { EPI group } \\
\text { PVB group }\end{array}$ & $\begin{array}{l}81(55-110) \\
87(55-119)\end{array}$ & $\begin{array}{l}82(60-109) \\
86(60-115)\end{array}$ & $\begin{array}{l}84(62-117) \\
88(62-124)\end{array}$ & $\begin{array}{l}86(65-112) \\
91(65-132)\end{array}$ & $\begin{array}{l}86(61-113) \\
93(61-120)\end{array}$ & $\begin{array}{l}87(70-113) \\
92(70-123)\end{array}$ & $\begin{array}{l}86(65-107) \\
90(65-107)\end{array}$ \\
\hline $\begin{array}{l}\mathrm{HR}^{*} \text { (beats/min) } \\
\text { EPI group } \\
\text { PVB group }\end{array}$ & $\begin{array}{l}74(45-120) \\
78(45-116)\end{array}$ & $\begin{array}{l}76(49-130) \\
82(50-130)\end{array}$ & $\begin{array}{l}73 \text { 48-115) } \\
81(48-129)\end{array}$ & $\begin{array}{l}77(52-132) \\
84(51-104)\end{array}$ & $\begin{array}{l}81(50-131) \\
84(54-109)\end{array}$ & $\begin{array}{l}76(52-134) \\
82(56-99)\end{array}$ & $\begin{array}{l}83(53-132) \\
88(59-100)\end{array}$ \\
\hline $\begin{array}{l}\mathrm{SpO}_{2}{ }^{*} \\
\mathrm{EPI} \text { group } \\
\mathrm{PVB} \text { group }\end{array}$ & $\begin{array}{l}98(92-100) \\
98(97-100)\end{array}$ & $\begin{array}{l}98(94-100) \\
97(92-100)\end{array}$ & $\begin{array}{l}97(94-100) \\
97(92-100)\end{array}$ & $\begin{array}{l}98(95-100) \\
97(91-100)\end{array}$ & $\begin{array}{l}98(93-100) \\
97(93-100)\end{array}$ & $\begin{array}{l}98(95-100) \\
98(94-100)\end{array}$ & $\begin{array}{l}98(92-100) \\
98(92-100)\end{array}$ \\
\hline
\end{tabular}

${ }^{*}$ Data presented as median (range; minimum-maximum); the repeated measure analysis of all parameters between groups showed $P>0.05$; EPI group - thoracic epidural group; PVB group - paravertebral group; SAP - systolic arterial pressure, DAP - diastolic arterial pressure, MAP - mean arterial pressure, HR - heart rate, $\mathrm{SpO}_{2}$ - peripheral oxygen saturation

Tab. IV. Comparison of postoperative visual analog scale scores during rest $(0 \mathrm{~cm}=$ no pain, $10 \mathrm{~cm}=$ worst pain imaginable) in both groups*

\begin{tabular}{lccccc} 
Time (hours) & \multicolumn{2}{c}{ Visual Analogue Score } & $\begin{array}{c}\text { Between groups } \\
\left(P^{*}\right)\end{array}$ & $\begin{array}{c}\text { Within EPI group } \\
\left(P^{*}\right)\end{array}$ & $\begin{array}{c}\text { Within PVB group } \\
\left(P^{*}\right)\end{array}$ \\
\cline { 2 - 4 } Basal & $4.9 \pm 2.5$ & $4.8 \pm 2$ & 0.82 & $\Delta$ & $\Delta$ \\
\hline 2 & $3.4 \pm 2.3$ & $4.6 \pm 2.3$ & 0.074 & $<0.0014^{\mathrm{a}}$ & $<0.0001^{\mathrm{b}}$ \\
\hline 4 & $1.6 \pm 1.7$ & $2.6 \pm 2.2$ & 0.054 & $<0.0001^{\mathrm{a}}$ & $<0.0001^{\mathrm{b}}$ \\
\hline 12 & $1.3 \pm 1.3$ & $2 \pm 1.7$ & 0.06 & $<0.0001^{\mathrm{a}}$ & $<0.0001^{\mathrm{b}}$ \\
\hline 24 & $1.1 \pm 1.3$ & $1.7 \pm 1.6$ & 0.104 & $<0.0001^{\mathrm{a}}$ & $<0.0001^{\mathrm{b}}$ \\
\hline
\end{tabular}

${ }^{*} p<0.05$, statistically significant; values are median (range), absolute numbers, or mean \pm standard deviation; EPI group - thoracic epidural group, PVB group paravertebral group ; ${ }^{a}$ Comparison to basal value in thoracic epidural group; ${ }^{b}$ Comparison to basal value in paravertebral group

Tab. V. Comparison of postoperative visual analog scale scores during coughing $(0 \mathrm{~cm}=$ no pain, $10 \mathrm{~cm}=$ worst pain imaginable $)$ in both groups*

\begin{tabular}{lccccc} 
Time (hours) & \multicolumn{2}{c}{ Visual Analogue Score } & $\begin{array}{c}\text { Between groups } \\
\left(P^{*}\right)\end{array}$ & $\begin{array}{c}\text { Within EPI group } \\
\left(P^{*}\right)\end{array}$ & $\begin{array}{c}\text { Within PVB group } \\
\left(P^{*}\right)\end{array}$ \\
\cline { 2 - 5 } Basal & $7.8 \pm 1.4$ & $7.7 \pm 1.5$ & 0.703 & $\Delta$ & $\Delta$ \\
\hline 2 & $4.1 \pm 1.1$ & $4.6 \pm 1.1$ & 0.082 & $<0.0001^{\mathrm{a}}$ & $<0.0001^{\mathrm{b}}$ \\
\hline 4 & $3 \pm 0.6$ & $3.3 \pm 0.7$ & 0.102 & $<0.0001^{\mathrm{a}}$ & $<0.0001^{\mathrm{b}}$ \\
\hline 12 & $2.3 \pm 0.7$ & $2.7 \pm 0.9$ & 0.131 & $<0.0001^{\mathrm{a}}$ & $<0.0001^{\mathrm{b}}$ \\
\hline 24 & $2 \pm 0.6$ & $2.2 \pm 0.4$ & 0.217 & $<0.0001^{\mathrm{a}}$ & $<0.0001^{\mathrm{b}}$ \\
\hline
\end{tabular}

${ }^{*} p<0.05$, statistically significant; values are median (range), absolute numbers, or mean \pm standard deviation; EPI group - thoracic epidural group, PVB group paravertebral group; ${ }^{a}$ Comparison to basal value in thoracic epidural group; ${ }^{b}$ Comparison to basal value in paravertebral group.

tients $(6.7 \%)$ in the PVB group $(p=0.038)$. The incidence of nausea and vomiting was $2 / 30(6.7 \%)$ in the EPI group compared to $6 / 30(20 \%)$ in the PVB group $(p=0.129)$. There was no significant difference between the EPI and PVB groups (Table VI). One patient with vomiting received dexamethasone treatment. Urinary retention could not be assessed, since patients routinely had Foley catheters inserted at the time of surgery.

There was no difference in operation time between groups EPI and PVB (257 \pm 75 min versus $244 \pm 78$ min; $p=0.512)$. There was no difference in the use of RBC (3.43 $\pm 0.54 \cup$ vs. $2.75 \pm 0.7 \mathrm{U} ; p=0.059)$ and FFP $(2.67 \pm 0.58 \mathrm{U}$ vs. $2.33 \pm 0.58 \mathrm{U} ; p=0.519)$ solutions between groups.

There was no significant difference in hospital length of stay ( 8 days vs. 10 days; $p=0.203$ ) between groups EPI and PVB (Table I). The postoperative 30-day mortality rates were similar between groups $(p>0.05)$ (Table VI).

\section{Discussion}

In the present study the efficacy of thoracic epidural and paravertebral block for pain relief in the postoperative period after thoracotomies was investigated by VAS scores, 
Tab. VI. Side effects related to postoperative analgesia and complications of the study groups in the 30-day postoperative period

\begin{tabular}{lccc}
$\begin{array}{l}\text { Nausea and } \\
\text { vomiting }\end{array}$ & $2(6.7)$ & $6(20)$ & 0.129 \\
\hline Hypotension & $8(26.7)$ & $2(6.7)$ & $0.038^{*}$ \\
\hline Bradycardia & $4(13.3)$ & $1(3.3)$ & 0.161 \\
\hline $\begin{array}{l}\text { Bronchopleural } \\
\text { fistula }\end{array}$ & $2(6.7)$ & $2(6.7)$ & 1 \\
\hline Rethoracotomy & $1(3.3)$ & 0 & 0.313 \\
\hline $\begin{array}{l}\text { In-hospital 30- } \\
\text { day mortality }\end{array}$ & $2(6.7)$ & $1(3.3)$ & 0.554 \\
\hline $\begin{array}{l}\text { Respiratory } \\
\text { complications }\end{array}$ & $18(60)$ & $9(30)$ & $0.02^{*}$ \\
\hline $\begin{array}{l}\text { Respiratory } \\
\text { failure }\end{array}$ & $5(16.7)$ & $1(3.3)$ & 0.085 \\
\hline Atelectasis & $4(13.3)$ & $1(3.3)$ & 0.161 \\
\hline $\begin{array}{l}\text { Pneumonia } \\
\text { Bronchoscopy } \\
\text { and suction }\end{array}$ & $4(13.3)$ & $2(6.7)$ & 0.389 \\
\hline $\begin{array}{l}\text { Mini-tracheosto- } \\
\text { my }\end{array}$ & 0 & $1(3.3)$ & 0.313 \\
\hline \begin{tabular}{l} 
Reintubated \\
\hline $\begin{array}{l}\text { EPl group - thoracic epidural group, PVB group - paravertebral group; } \\
\text { - statistically significant }\end{array}$
\end{tabular} & $2(6.3)$ & 0.05 \\
\hline
\end{tabular}

total analgesic consumption and the incidence of adverse events. Our data support several studies in the literature indicating that both thoracic epidural and paravertebral block techniques provide a comparable amount of pain relief during the period of the first 24 hours postoperatively. However, paravertebral block provides a better adverse effect profile and it can be an easier and quicker technique than thoracic epidural technique [4, 7, 9]. Davies et al. [9] reported a meta-analysis of ten randomized controlled trials, including 520 patients during the period of 1989 to 2005 and found that there was no significant difference in epidural and paravertebral analgesia for pain scores. The other important finding of this study was to show that paravertebral block technique provides a decrease in the pulmonary complications such as pneumonia and atelectasis [8-10].

Patients undergoing thoracotomy may suffer from severe postoperative pain. In addition, pulmonary functions show impairment after surgery and may be worsened by the effects of pain. Therefore, the risk of pulmonary complications such as chest infection, atelectasis, sputum retention, and acute lung injury may be reduced if analgesia is managed effectively [11]. In a recent study by Elsayed et al. [12], no significant difference between thoracic epidural analgesia and paravertebral block in the incidence of postoperative respiratory complications was observed [12]. However, the pathophysiological mechanisms related to better lung functions with PVB can be listed as: 1 - cause dense somatic afferent blockade, 2 - completely block transmission within the sympathetic chain. Richardson and co-workers showed that PVB is capable of completely abolishing somatosensory evoked potential (SSEP) in a number of adjacent dermatomal segments [8]. In this study, it has been demonstrated that patients having the paravertebral block showed higher oxygen saturations and lower respiratory morbidity (decreased incidence of chest infection) postoperatively. Our data also support their findings that the incidence of respiratory function related complications was lower in the PVB group [9 patients (30\%)] in comparison to the EPI group [18 patients $(60 \%)](p=0.02)$. We think that this is an important finding that needs further investigation as to whether the paravertebral block should be considered routinely after thoracotomy procedures as it is related to lower incidence of respiratory related complications. PVB block was accompanied by quicker return to normal pulmonary function [13].

In our study, total local anesthetic doses, total morphine and total other analgesic doses did not show any significant differences. Our findings are also supported by the study of Gulbahar et al. [14] in which no significant differences were observed in VAS scores, additional morphine sulfate consumption, arterial blood gas values, oxygen saturations, total hospital stay and postoperative pulmonary morbidities between thoracic epidural analgesia and PVB groups. Our study supports their findings that there were no differences between groups regarding VAS scores. The use of PVB causes diminished pain in the back and lateral side of the chest secondary to nerve block effects of PVB on ipsilateral sympathetic chain, posterior rami and intercostal nerves and these actions caused decreased straining of posterior spinal muscles and ligaments. In addition, injection into the subendothoracic compartment would be expected to spread more easily to other dermatomes and to the contralateral side. In their study, in the thoracic epidural analgesia group side-effects such as urinary retention (21\%), nausea (26\%), vomiting (16\%) and hypotension (11\%) were more commonly observed in comparison to the PVB group. We also found that arterial blood gas values and oxygen saturations were similar between the two groups, with higher incidence of hypotension in the EPI group. The incidence of urinary retention was not collectable as all patients had Foley catheters in the first 24 hours postoperatively.

The time for insertion of the PVB catheter in the study by Gulbahar et al. [14] was half of the time in our study (4.24 $\pm 0.72 \mathrm{~min}$ vs. $5.27 \pm 0.9 \mathrm{~min}$ ). Our findings are similar date time for insertion of catheters were identical.

In the study by Detterbeck et al. [15] 619 patients from 17 trials were analyzed in a review study. It was shown that PVB provides good pain relief in comparison to thoracic epidural analgesia. Better preservation of the $\mathrm{FEV}_{1}$ was shown in 16 trials. Thoracic epidural analgesia was associated with frequent side-effects and was associated with technical failure or displacement (8\%); however, PVB has fewer side-effects and is an easier and quicker method. Our findings are in agreement with this review study as the duration for catheter placement was shorter in the PVB group than in the EPI group.

In the study by Cucu et al. [16] EPI and PVB analgesia methods were compared using continuous infusion of 
$0.25 \%$ bupivacaine for 24 hours for thoracotomies and they reported similar pain scores, additional morphine sulfate consumption, incidence of side effects and hemodynamic parameters. Our findings are similar to the study by Cucu et al. [16] in that there was no significant difference in postoperative 24-hour arterial blood gas values; however, we found a higher incidence of hypotension in the EPI group in comparison to PVB.

In a systematic review, it was reported that the use of adjuvant clonidine or fentanyl, pre-emptive PVB, and the addition of patient-controlled opioids to PVB did not improve analgesia. Further well-designed trials of different PVB dosage and drug regimens are needed [17]. Our study also has limitations as we did not include in the study design different doses of local anesthetics through the PVB catheter and there is a need for a larger group of patients although the sample size was calculated to be sufficient.

In the study by Kanazi et al. [10], thoracic epidural analgesia provided less morphine consumption ( $9 \mathrm{mg} v \mathrm{vs} .36 \mathrm{mg}$ ) in comparison of EPI and PVB groups after thoracotomy surgery, while pain scores were similar. In the study by Casati et al. [7], there was a statistically significant $(p=0.003)$ increase in median $\left(25^{\text {th }}-75^{\text {th }}\right.$ percentiles) patient-controlled use of morphine, with values of 36 (22-42) $\mathrm{mg}$ in the paravertebral group vs. 9 (2-22) mg in the epidural group. This increase in morphine usage in the paravertebral group was statistically significant at 6, 24, 48, and 72 hours after surgery. Postoperative pain measured with the VAS was not significantly different in the two groups. Better spirometer values at $72 \mathrm{~h}$ were observed in the epidural group than in the paravertebral group $(p=0.03)$ [7]. We were not able to support their findings as no significant difference in total 24-hour morphine consumption was observed between our study groups.

In another prospective, randomized, blinded study for post-thoracotomy pain continuous $0.2 \%$ ropivacaine infusion (infusion rate: $5-10 \mathrm{ml} / \mathrm{h}$ ) was given to both EPI and PVB groups. The quality of analgesia was found to be similar, while hypotension evaluated in the EPI group (19\%) was found to be higher [7]. In an other study on lung resection, enough analgesia was evaluated with both the paravertebral and the epidural method by applying continuous $0.375 \%$ ropivacaine infusion [18]. They reported enough analgesia and similar amounts of total ropivacaine consumption and rescue analgesia with both paravertebral and epidural methods. Arterial blood gas values were better and the incidence of hypotension was meaningfully lower in the PVB group [18]. There were no differences in VAS-R and VAS-C, consumption of additional morphine sulfate, respiratory parameters, or length of intensive care unit and hospital stay, and incidence of pulmonary complications was similar in both groups in the study by Mohta et al. [18] regarding all studies above, but they reported more hypotension in the EPI group. Pintaric et al. [19] observed similar heart rate and mean arterial blood pressure in EPI and PVB groups, while SAP values were lower, and phenylephrine consumption was meaningfully higher in the EPI group in their series treating analgesia of lung surgery with levobupivacaine and morphine.

Additional research is required to compare the efficacy and safety of continuous paravertebral block using ultrasound-guided techniques or surgical inserted catheters [20]. This mode of analgesia is not considered to be a stand alone technique (in contrast to epidural analgesia) and most patients will require additional analgesia (usually parenteral patient controlled analgesia). Compared to epidural analgesia, the paravertebral administration of analgesia is considered to be safer in anti-coagulated patients, but the risk of local anesthetic toxicity remains.

Continuous thoracic paravertebral analgesia is considered to be as effective as the epidural blockade in controlling post-thoracotomy pain, but it is associated with fewer hemodynamic effects [21-24]. Under the conditions of our study, continuous paravertebral block resulted in similar analgesia but greater hemodynamically stability than epidural analgesia in patients having thoracotomy. Paravertebral block also required a smaller volume of colloids and vasopressors to maintain the target oxygen delivery index [19]. Our study also showed no significant difference in hemodynamic parameters between the two groups. There are also studies which suggest that epidural analgesia is more efficient than the paravertebral continuous block at reducing pain after thoracic surgery with no deterioration in mean arterial blood pressures and heart rates [25].

Batra et al. [26] in their review mentioned that there are many techniques in PVB as conventional techniques of paravertebral space localization include loss of resistance following penetration of the superior costotransverse ligament, use of a nerve stimulator or ultrasound guidance, and use of ultrasound and contrast dye. Paravertebral injections and catheter insertion can be performed in sedated and ventilated patients with less risk of neuraxial injury. The catheters can also be safely and correctly placed during thoracotomy.

\section{Conclusions}

In summary, both thoracic epidural and paravertebral block techniques provide sufficient pain relief for post-thoracotomy pain. Paravertebral block is an easier and quicker technique with less hypotension; therefore it should be considered as a good alternative to thoracic epidural technique to establish postoperative analgesia. Major limitations of our study were the small group of patients and lack of a control group. Therefore, there is a need for a larger group of patients to be evaluated in clinical, double-blinded randomized trials.

\section{References}

1. Merskey H, Bogduk N. Classification of chronic pain: Description of chronic pain syndromes and definitions of pain terms. Seattle, Wash: International Association for the Study of Pain; 1994.

2. Ready LB. Acute pain: lessons learned from 25,000 patients. Reg Anesth Pain Med 1999; 24: 499-505.

3. Ballantyne JC, Carr DB, deFerranti S, Suarez T, Lau J, Chalmers TC, Angelillo IF, Mosteller F. The comparative effects of postoperative analgesic therapies on pulmonary outcome: cumulative meta-analyses of randomized, controlled trials. Anesth Analg 1998; 86: 598-612. 
4. Joshi GP, Bonnet F, Shah R, Wilkinson RC, Camu F, Fischer B, Neugebauer EA, Rawal N, Schug SA, Simanski C, Kehlet H. A systematic review of randomized trials evaluating regional techniques for postthoracotomy analgesia. Anesth Analg 2008; 107: 1026-1040.

5. Fibla JJ, Molins L, Mier JM, Sierra A, Vidal G. Comparative analysis of analgesic quality in the postoperative of thoracotomy: paravertebral block with bupivacaine $0.5 \%$ vs ropivacaine $0.2 \%$. Eur J Cardiothorac Surg 2008; 33: 430-434.

6. Charlson ME, Pompei P, Ales KL, MacKenzie CR. A new method of classifying prognostic comorbidity in longitudinal studies: Development and Validation. J Chronic Dis 1987; 40: 373-383.

7. Casati A, Alessandrini P, Nuzzi M, Tosi M, lotti E, Ampollini L, Bobbio A, Rossini E, Fanelli G. A prospective, randomized, blinded comparison between continuous thoracic paravertebral and epidural infusion of $0.2 \%$ ropivacaine after lung resection surgery. Eur J Anaesthesiol 2006; 23: 999-1004.

8. Richardson J, Sabanathan S, Jones J, Shah RD, Cheema S, Mearns AJ. A prospective randomized comparison of preoperative and continuous balanced epidural or paravertebral bupivacaine on post-thoracotomy pain, pulmonary function and stress response. Br J Anaesth 1999; 83: 387-392.

9. Davies RG, Myles PS, Graham JM. A comparison of the analgesic efficacy and side-effects of paravertebral vs epidural blockade for thoracotomy a systematic review and meta-analysis of randomized trials. $\mathrm{Br} J$ Anaesth 2006; 96: 418-426.

10. Kanazi GE, Ayoub CM, Aouad M, Abdallah F, Sfeir PM, Adham AB, El-Khatib MF. Subpleural block is less effective than thoracic epidural analgesia for post-thoracotomy pain: a randomised controlled study. Eur J Anaesthesiol 2012; 29: 186-191.

11. Richardson J, Sabanathan S, Mearns AJ, Shah RD, Goulden C. A prospective, randomized comparison of interpleural and paravertebral analgesia in thoracic surgery. Br J Anaesth 1995; 75: 405-408.

12. Elsayed H, McKevith J, McShane J, Scawn N. Thoracic epidural or paravertebral catheter for analgesia after lung resection: is the outcome different? J Cardiothorac Vasc Anesth 2012; 26: 78-82.

13. Scarci M, Joshi A, Attia R. In patients undergoing thoracic surgery is paravertebral block as effective as epidural analgesia for pain management? Interact Cardiovasc Thorac Surg 2010; 10: 92-96.

14. Gulbahar G, Kocer B, Muratli SN, Yildirim E, Gulbahar O, Dural K, Sakinci U. A comparison of epidural and paravertebral catheterisation techniques in postthoracotomy pain management. Eur J Cardiothorac Surg 2010; 37: 467-472.
15. Detterbeck FC. Efficacy of methods of intercostal nerve blockade for pain relief after thoracotomy. Ann Thorac Surg 2005; 80: 1550-1559.

16. Cucu O, Karaca P, Enc Y, Yücel O, Aksoy T, Senay S, Canik S. Comparison of thoracic paravertebral and epidural blocks for pain relief after thoracotomy. Turkish J Thorac Cardiovasc Surg 2006; 14: 42-47.

17. Kotzé A, Scally A, Howell S. Efficacy and safety of different techniques of paravertebral block for analgesia after thoracotomy: a systematic review and metaregression. Br J Anaesth 2009; 103: 626-636.

18. Mohta M, Verma P, Saxena AK, Sethi AK, Tyagi A, Girotra G. Prospective, randomized comparison of continuous thoracic epidural and thoracic paravertebral infusion in patients with unilateral multiple fractured ribs - a pilot study. J Trauma 2009; 66: 1096-1101.

19. Pintaric TS, Potocnik I, Hadzic A, Stupnik T, Pintaric M, Jankovic VN. Comparison of continuous thoracic epidural with paravertebral block on perioperative analgesia and hemodynamic stability in patients having open lung surgery. Reg Anesth Pain Med 2011; 36: 256-260.

20. Luyet C, Siegenthaler A, Szucs-Farkas Z, Hummel G, Eichenberger U, Vogt A. The location of paravertebral catheters placed using the landmark technique. Anaesthesia 2012; 67: 1321-1326.

21. Norum HM, Breivik $H$. Learning from the past for the present: paravertebral blocks for thoracic surgery are not without risk. Eur J Anaesthesiol 2011; 28: 544-545.

22. Zeid HA, Siddiqui AK, Elmakarem EF, Ghonaimy Y, Al Nafea A. Comparison between intrathecal morphine with paravertebral patient controlled analgesia using bupivacaine for intraoperative and post-thoracotomy pain relief. Saudi J Anaesth 2012; 6: 201-206.

23. Helms O, Mariano J, Hentz JG, Santelmo N, Falcoz PE, Massard G, Steib A. Intra-operative paravertebral block for postoperative analgesia in thoracotomy patients: a randomized, double-blind, placebo-controlled study. Eur J Cardiothorac Surg 2011; 40: 902-906.

24. Dango S, Harris S, Offner K, Hennings E, Priebe HJ, Buerkle H, Passlick B, Loop T. Combined paravertebral and intrathecal vs thoracic epidural analgesia for post-thoracotomy pain relief. Br J Anaesth 2013; 110: 443-449.

25. Messina M, Boroli F, Landoni G, Bignami E, Dedola E, N'zepa Batonga J, Magrin A, Zangrillo S. A comparison of epidural vs. paravertebral blockade in thoracic surgery. Minerva Anestesiol 2009; 75: 616-621.

26. Batra RK, Krishnan K, Agarwal A. Paravertebral block. J Anaesthesiol Clin Pharmacol 2011; 27: 5-11. 